\title{
The Influence Of Intensity And Habits Learning On Mathematical Critical Thinking Ability
}

\section{Dian Purwaningsih}

\author{
Jurusan Pendidikan Matematika Universitas Peradaban \\ dian.purwaningsih24@yahoo.com
}

\begin{abstract}
The problems often faced by students in the learning process are the ability to solve mathematical problems. The process of solving mathematical problems requires thinking skills. Thinking skills needed to provide creative ideas in solving mathematical problems include critical thinking skills. The understanding of students in providing creative ideas is still low and the ability of students to identify a mathematical problem is still low. The purpose of this study was to determine the effect of learning intensity on the ability to think critically mathematically, to determine the effect of learning habits on mathematical critical thinking skills, to determine the effect of learning intensity and learning habits on mathematical critical thinking skills. This type of research is explanatory research. The results of this study, namely there is a positive influence on learning intensity on mathematical critical thinking skills, there is a positive influence on learning habits on mathematical critical thinking skills, there is a positive influence on intensity and learning habits on mathematical critical thinking skills.
\end{abstract}

Keywords: intensity, habits, mathematical critical thinking

\section{INTRODUCTION}

Learning is needed by everyone, because learning can provide a person's experience in his life. Based on this, learning will provide changes in one's behavior. According Sudjana (2005: 5) suggests that learning is a process that is characterized by changes in a person. Changes in behavior that everyone has varies depending on the learning process carried out. Learning takes a technique or a way so that something that is received can be understood well, so that success can be achieved. According to Djaali (2009: 101) revealed the factors that influence success in the learning process include motivation, attitudes, interests, study habits and self-concept.

According to Rana and Kausar (Budijanto, 2016: 18) argues that the main key to successful student learning is good learning habits. Meanwhile, according to Sardiman (Ristanti, 2016: 93) states that the learning intensity of students will determine the level of achievement of learning objectives, namely improving their achievement. Based on this, sufficient learning intensity and routine learning habits can provide a change in student learning outcomes. The process of increasing learning outcomes, students need to be equipped with certain abilities in dealing with various problems of everyday life. The problems often faced by students in the learning process are the ability to solve mathematical problems. The process of solving mathematical problems requires thinking 
skills. According to Selz (Suryabrata, 2004: 64) argues that thinking is an abstract activity, in a direction determined by a problem that must be solved

Thinking skills needed to provide creative ideas in solving mathematical problems include critical thinking skills. According to Krulik and Rudnik (Abdullah, 2013: 72) suggests that critical thinking is grouping, organizing, remembering and analyzing the information needed, testing, connecting and evaluating all aspects of the problem situation.

Based on the observations of student behavior towards the readiness to accept the material, it can be seen from the students' understanding in providing creative ideas and solving mathematical problems. The understanding of students is still low and the ability of students to identify a mathematical problem is still low. This can also result in low students' critical thinking skills.

Based on the background of the problem, the objectives of this study are as follows: (a) to determine the effect of learning intensity on critical thinking skills, (b) to determine the effect of learning habits on mathematical critical thinking skills, (c) to determine the effect of learning intensity and habits learn about mathematical critical thinking skills

\section{RESEARCH METHOD}

This type of research is explanatory research (explanation) that is research that explains the position of the variables studied and the relationship between one variable with another variable (Sugiyono, 2011). This research approach is a quantitative approach. This research was carried out at the University of Civilization in the 2017/2018 school year. The population of this study were students of Mathematics Education Department of the University of Civilization in the sixth semester of Academic Year 2017/2018. Independent variables (independent variables) in this study are learning intensity and study habits. The dependent variable (dependent variable) in this study is the ability to think critically mathematically. The research instruments used were observation sheets, questionnaire sheets and test sheets. Data collection was carried out by questionnaire method, observation method, and test method. Analysis of the data used in this study is a regression analysis test.

\section{RESULT AND DISCUSSION}

In this study a regression test analysis was conducted to determine the effect of learning intensity and learning habits on the communication skills of mathematical critical thinking. This analysis test uses SPPS.

1. Effect of learning intensity on mathematical critical thinking skills used simple regression

a) To analyze the effect of learning intensity on mathematical critical thinking skills obtained results can be seen in the following table. 
Tabel 1. ANOVA

\begin{tabular}{|c|c|c|c|c|c|c|}
\hline \multicolumn{2}{|c|}{ Model } & Sum of Squares & $\mathrm{df}$ & Mean Square & $\mathrm{F}$ & Sig. \\
\hline 1 & $\begin{array}{l}\text { Regressi } \\
\text { on }\end{array}$ & 1748.276 & 1 & 1748.276 & 21.958 & $.000^{\mathrm{a}}$ \\
\hline & Residual & 1035.057 & 13 & 79.620 & & \\
\hline & Total & 2783.333 & 14 & & & \\
\hline
\end{tabular}

From the results of the data above obtained $\mathrm{F}=21.958$ with sig $0,00<0,05$, which means that $\mathrm{H}_{0}$ is rejected, meaning that the simple regression equation of learning intensity affects the ability to think critically mathematically.

b) To measure the magnitude of the effect of learning intensity on mathematical critical thinking skills can be seen in the following table.

Tabel 2. Model Summary

\begin{tabular}{|c|c|c|c|c|}
\hline \multicolumn{5}{|c|}{ Adjusted R } \\
\hline Model & $\mathrm{R}$ & R Square & Square & Std. Error of the Estimate \\
\hline 1 & $.793^{\mathrm{a}}$ & .628 & .600 & 8.923 \\
\hline
\end{tabular}

The amount of influence can be seen from the value of $R$ square $=0,628=62,8 \%$ which means that $62,8 \%$ of mathematical critical thinking ability is influenced by the intensity of learning and the rest is influenced by other factors.

c) To find out the form of regression equation can be seen in the following table.

Tabel 3. Coefficients

\begin{tabular}{|c|c|c|c|c|c|c|}
\hline \multirow{2}{*}{\multicolumn{2}{|c|}{ Model }} & \multicolumn{2}{|c|}{$\begin{array}{l}\text { Unstandardized } \\
\text { Coefficients }\end{array}$} & \multirow{2}{*}{$\begin{array}{c}\text { Standardized } \\
\text { Coefficients } \\
\text { Beta }\end{array}$} & \multirow[b]{2}{*}{$\mathrm{t}$} & \multirow[b]{2}{*}{ Sig. } \\
\hline & & $\mathrm{B}$ & Std. Error & & & \\
\hline 1 & $\begin{array}{l}\text { (Constan } \\
\text { t) }\end{array}$ & -122.149 & 41.851 & & -2.919 & .012 \\
\hline & $\mathrm{x} 1$ & 3.102 & .662 & .793 & 4.686 & .000 \\
\hline
\end{tabular}

The table above can be seen the relationship of learning intensity to mathematical critical thinking abilities shown in the regression equation. The form of the regression equation is yaitu $\hat{Y}=-122,149+3,102 x_{1}$, meaning that each addition to the learning intensity variable is one unit, it will increase the value of mathematical critical thinking ability by 3,102 , so $\mathrm{H}_{0}$ is rejected and accept $\mathrm{H}_{1}$. Based on this, it means that learning intensity has a positive effect on mathematical critical thinking skills

2. The influence of study habits on mathematical critical thinking skills is used simple regression and obtained results can be seen in the following table.

a) To analyze the influence of study habits on mathematical critical thinking skills, the results can be seen in the following table 
Tabel 4. ANOVA

\begin{tabular}{lrrrrr}
\hline & & \multicolumn{4}{c}{ Mean } \\
Model & Sum of Squares & df & Square & \multicolumn{1}{c}{ F } & Sig. \\
\hline 1 Regression & 1766.755 & 1 & 1766.755 & 22.593 & $.000^{\mathrm{a}}$ \\
Residual & 1016.578 & 13 & 78.198 & & \\
$\quad$ Total & 2783.333 & 14 & & & \\
\hline
\end{tabular}

From the results of the data above obtained $F=22,593$ with sig $0,00<0,05$, which means that $\mathrm{H} 0$ is rejected, meaning that a simple regression equation of learning habits affects the ability to think critically mathematically.

b) To measure the magnitude of the influence of study habits on mathematical critical thinking skills can be seen in the following table

Tabel 5. Model Summary

\begin{tabular}{lrrrr}
\hline Model & R & R Square & $\begin{array}{c}\text { Adjusted R } \\
\text { Square }\end{array}$ & $\begin{array}{c}\text { Std. Error of the } \\
\text { Estimate }\end{array}$ \\
\hline 1 & $.797^{\mathrm{a}}$ & .635 & .607 & 8.843 \\
\hline
\end{tabular}

The amount of influence can be seen from the value of $R$ square $=0,635=63,5 \%$ which means $63,5 \%$ of mathematical critical thinking abilities are influenced by study habits and the rest is influenced by other factors.

c) To find out the form of regression equation can be seen in the following table

Tabel 6. Coefficients

\begin{tabular}{|c|c|c|c|c|c|c|}
\hline \multirow{2}{*}{\multicolumn{2}{|c|}{ Model }} & \multicolumn{2}{|c|}{$\begin{array}{l}\text { Unstandardized } \\
\text { Coefficients }\end{array}$} & \multirow{2}{*}{$\begin{array}{c}\begin{array}{c}\text { Standardize } \\
\mathrm{d} \\
\text { Coefficients }\end{array} \\
\text { Beta }\end{array}$} & \multirow[b]{2}{*}{$\mathrm{t}$} & \multirow[b]{2}{*}{ Sig. } \\
\hline & & $\mathrm{B}$ & Std. Error & & & \\
\hline \multirow[t]{2}{*}{1} & (Constant) & -9.293 & 17.602 & & -.528 & .606 \\
\hline & $\mathrm{x} 2$ & 1.157 & .243 & .797 & 4.753 & .000 \\
\hline
\end{tabular}

The table above can be seen the relationship of learning habits to mathematical critical thinking skills shown in the regression equation. The form of the regression equation is $\hat{Y}=-9,293+1,157 x_{2}$, meaning that each addition to the study habits variable is one unit, it will add the value of critical thinking skills of 1.157, so that $\mathrm{H}_{0}$ is rejected and accepted $\mathrm{H}_{1}$. Based on this, it means that learning habits have a positive effect on mathematical critical thinking skills.

3. The effect of intensity and study habits on mathematical critical thinking skills used multiple regression and obtained results can be seen in the following table.

a) To analyze the effect of intensity and study habits on mathematical critical thinking skills obtained results can be seen in the following table. 
Tabel 7. ANOVA

\begin{tabular}{|c|c|c|c|c|c|c|}
\hline \multicolumn{2}{|c|}{ Model } & Sum of Squares & df & Mean Square & $\mathrm{F}$ & Sig. \\
\hline 1 & $\begin{array}{l}\text { Regressi } \\
\text { on }\end{array}$ & 2151.184 & 2 & 1075.592 & $\begin{array}{r}20.41 \\
8\end{array}$ & $.000^{\mathrm{a}}$ \\
\hline & Residual & 632.149 & 12 & 52.679 & & \\
\hline & Total & 2783.333 & 14 & & & \\
\hline
\end{tabular}

From the results of the data above obtained $\mathrm{F}=20.418$ with sig $0.00<0.05$, which means that $\mathrm{H} 0$ is rejected, meaning that the multiple regression equation intensity and learning habits affect the ability to think critically mathematically.

b) To measure the magnitude of the effect of intensity and study habits on mathematical critical thinking skills can be seen in the following table.

Tabel 8. Model Summary

\begin{tabular}{llrrrr}
\hline Model & R & R Square & $\begin{array}{c}\text { Adjusted R } \\
\text { Square }\end{array}$ & \multicolumn{2}{c}{$\begin{array}{c}\text { Std. Error of the } \\
\text { Estimate }\end{array}$} \\
\hline 1 & $.879^{\mathrm{a}}$ & .773 & .735 & & 7.258 \\
\hline
\end{tabular}

The amount of influence can be seen from the value of $\mathrm{R}$ square $=0.773=77.3 \%$ which means $77.3 \%$ of mathematical critical thinking abilities are influenced by the intensity and study habits while the rest is influenced by other factors.

c) To find out the form of regression equation can be seen in the following table.

Tabel 9. Coefficients

\begin{tabular}{|c|c|c|c|c|c|c|c|}
\hline \multirow{2}{*}{\multicolumn{2}{|c|}{ Model }} & \multicolumn{2}{|c|}{$\begin{array}{c}\text { Unstandardized } \\
\text { Coefficients }\end{array}$} & \multirow{2}{*}{\multicolumn{2}{|c|}{$\begin{array}{c}\text { Standardized } \\
\text { Coefficients } \\
\text { Beta } \\
\end{array}$}} & \multirow[b]{2}{*}{$\mathrm{t}$} & \multirow[b]{2}{*}{ Sig. } \\
\hline & & B & Std. Error & & & & \\
\hline \multirow[t]{3}{*}{1} & (Constant) & -97.930 & 34.529 & & & -2.836 & .015 \\
\hline & $\mathrm{x} 1$ & 1.871 & .660 & & .478 & 2.836 & .015 \\
\hline & $\mathrm{x} 2$ & .752 & .248 & & .511 & 3.028 & .011 \\
\hline
\end{tabular}

The table above can be seen the relationship between intensity and learning habits of mathematical critical thinking skills shown in the regression equation. The form of the regression equation is $\hat{Y}=-97,930+1,871 x_{1}+0,752 x_{2}$, meaning that each addition to the variable learning intensity is one unit, it will increase the value of mathematical critical thinking ability by 1,871 , and each addition of study habits variable by one unit, it will add the value of critical thinking ability is 0.752 , so $\mathrm{H} 0$ is rejected and accept $\mathrm{H} 1$. Based on this, it means that the intensity and study habits are equally positive for the ability to think critically mathematically. 


\section{CONCLUSION}

The conclusion of this study is that there is a positive influence on learning intensity on mathematical critical thinking skills, there is a positive influence on learning habits on mathematical critical thinking skills, there is a positive influence on intensity and learning habits on mathematical critical thinking skills. The regression equation can be used as a basis for predicting mathematical critical thinking skills if the intensity and learning habits are known.

\section{REFERENCES}

Abdullah, H. 2013. Berpikir Kritis Matematis. Delta-Pi:Jurnal Matematika dan Pendidikan Matematika Vol.2 No.1 April 2013, ISSN 2089-855X.

Budijanto, dkk. 2016. Pengaruh Kebiasaan Belajar dan Self-Efficacy Terhadap Hasil Belajar Geografi di SMA. Jurnal Pendidikan Geografi Tahun 21, No.2 Juni 2016, hal. 17-28. Tersedia di: http://Journal.um.ac.id/index.php/pendidikan-geografi/ index

Djaali. 2009. Psikologi Pendidikan. Jakarta: Bumi Aksara.

Hariyanto, dkk. 2012. Belajar dan Pembelajaran. Bandung: PT Remaja Rosdakaya.

Karim, N. 2015. Kemampuan Berpikir Kritis Siswa dalam Pembelajaran Matematika dengan Menggunakan Model Jucama di Sekolah Menengah Pertama. Edu-Mat Jurnal Pendidikan Matematika Vol.3 No.1 April 2015, hal 92-104. Tersedia di: http://ppjp.unlam.ac.id/journal/index.php/edumat/article/download/634/542

Mahmuzah, R. 2015. Peningkatan Kemampuan Berpikir Kritis Matematis Siswa SMP Melalui Pendekatan Problem Posing. Jurnal Juang Vol.4 No.1 Oktober 2015, ISSN: 2302-5158. Tersedia di: http://www.jurnal.unsyiah.ac.id/peluang/article/ download/5860/4852

Napituplu dan Hasratuddin. 2015. Peningkatan kemampuan Berpikir Kritis Matematis dan Kemandirian Belajar Siswa SMP Melalui Pembelajaran Berbasis Masalah. AdMathEdu Vol.5 No.1 Juni 2015, ISSN: 2088-687X. Tersedia di: http://journal.uad.ac.id/index.php/AdMmathEdu/article/download/4786/3148

Nurhayati. 2010. Pengaruh Sikap dan Kebiasaan Belajar Terhadap Hasil Belajar Matematika . Jurnal Formatif 1(3): 247-254, ISSN: 2088-351X. Tersedia di: http://journal.lppmunindra.ac.id/index.php/Formatif/article/download/77/76

Ristanti, dkk. 2016. Hubungan Antara Kedisiplinan Siswa, Lingkungan social dan Intensitas Belajar dengan Prestasi Belajar Fisika. Vol.3 No.3 Desember 2016. Tersedia di: http://jurnal.ustjogja.ac.id/index.php/COMPTON/article/download/ $\underline{689 / 1005}$

Sholikhah, S. 2010. Hubungan Intensitas dan motivasi Belajar dengan Prestasi Belajar Mahasiswa S1 Keperawatan STIKes Muhammadiyah Lamongan. Surakarta: Universitas Sebelas Maret. 
Sudjana, N. 2005. Dasar-Dasar Proses Belajar-Mengajar. Bandung: Sinar Baru.

Sugiyono. 2011. Metode Penelitian Kuantitatif, Kualitatif dan R\&D. Bandung: Alfabeta

Sukestiyarno. 2010. Olah Data Penelitian Berbantuan SPSS. Universitas Negeri Semarang.

Suryabrata, S. 2004. Psikologi Pendidikan. Jakarta: PT RajaGrafindo Persada.

Syah, M. 2011. Psikologi Pendidikan. Bandung: PT Remaja Rosdakary. 